\title{
Politički subjekti u odnosu prema reformnom pokretu i starokatolicizmu - političko djelovanje radi slabljenja Katoličke Crkve u Kraljevini SHS-u do 1929. godine (I.)
}

\author{
DANiel PATAFTA* \\ • https://doi.org/10.31823/d.28.4.3 • \\ UDK: 272:32(497.1)“1918/1929“ • Izvorni znanstveni rad \\ Primljeno: 23. studenoga 2019. • Prihvaćeno: 2. prosinca 2020.
}

${ }^{*}$ Doc. dr. sc. Daniel Patafta, Katolički bogoslovni fakultet Sveučilišta u Zagrebu, Vlaška ulica 38, p. p. 432, 10000 Zagreb, Hrvatska, d.patafta@yahoo.com

Sažetak: Hrvatska starokatolička Crkva nastala je krajem 1923. godine kao neuspjeli pokušaj reformnoga pokreta dijela nižega katoličkoga klera koji je u razdoblju od 1919. do kraja 1923. težio za reformom i demokratizacijom Katoličke Crkve u Kraljevini Srba, Hrvata i Slovenaca, ali i na poticaj beogradskih vlada, u početku samostalnih demokrata Svetozara Pribićevića, povezanih sa slobodnim zidarima, a kasnije velikosrpske Radikalne stranke, koje su joj davale izravnu i neizravnu podršku u institucionaliziranju i širenju, pokazujući time svoj antagonizam prema katolicizmu. Svi politicki subjekti do 1929. godine koji su podržavali reformni pokret i Hrvatsku starokatoličku Crkvu činile su to iz političkoga oportunizma radi slabljenja društvenoga i političkoga utjecaja Katoličke $\mathrm{Cr}$ kve u hrvatskom narodu, ali i iz vlastitih ideoloških uvjerenja.

Ključne riječi: reformni pokret, Hrvatska starokatolicka Crkva, politički katolicizam, Pribićević, Stjepan Radić, srpski radikali, slobodni zidari, Katolicka Crkva, politicki oportunizam.

\section{Uvod}

Liberalni procesi u Europi, potaknuti različitom ideološkom podlogom, postupno su pokretali i u hrvatskim ze- 
mljama mnoge modernizacijske procese, ali su liberalne ideje pred Crkvu stavljale novi izazov i tražile reakciju. ${ }^{1}$ Nakon građanskoga liberalizma 19. stoljeća, početkom 20. stoljeća pojavio se u Hrvatskoj novi tip liberalizma koji su pod utjecajem ideja Tomáša Garriguea Masaryka ${ }^{2}$ donosili hrvatski praški studenti. Braća Antun i Stjepan Radić nudili su novu ideologiju za hrvatsko selo koja je uključivala i rastući bunt protiv utjecaja katoličkoga svećenstva u političkom životu Hrvatske. Unutar krugova novih liberala sve se više počelo govoriti protiv Rima, koji je vjerom i latinizmom podjarmio mnoge narode svomu političkom utjecaju, jer jedini neslobodni slavenski narodi jesu katolički narodi. Počelo se idealizirati pravoslavlje kao narodno i govoriti o stvaranju narodne Crkve u Hrvatskoj koja bi bila neovisna o Rimu. ${ }^{3}$

Uvjeti za početak reformnoga pokreta katoličkoga nižega klera postavljeni su u vrijeme postojanja Austro-Ugarske Monarhije. Nestankom Monarhije 1918. godine slomio se stoljetni društveni i politički okvir u kojem je Katolička Crkva bila jedan od važnih stupova habsburške dinastije te povijesna stvarnost koja je dosta suvereno oblikovala društveni i politički život. Liberalizam koji je krajem 19. i početkom 20. stoljeća dobio različite ideološke i političke smjerove odrazio se i u novoj političkoj stvarnosti u kojoj se 1918. godine našla Katolička Crkva u hrvatskom narodu. Nezadovoljstvo dijela nižega katoličkoga klera, utjecaj različitih političkih ideja i nova društveno-politička stvarnost nastala osnivanjem Kraljevine SHS-a/

\footnotetext{
${ }^{1}$ Usp. S. RITIG, Restauracija katolicizma u vrijeme narodnog preporoda, u: Bogoslovska smotra 20(1933.)2, 97-110.; S. RITIG, Restauracija katolicizma u vrijeme narodnog preporoda, u: Bogoslovska smotra 21(1933.)2, 105-123.; J. LAHNER, Gajeva demonstracija protiv zagrebačkome biskupu Hauliku, u: Croatia sacra 13-14(1944.)22-23, 61-71.; S. KOSTRENČIĆ, Jedna rič gospodinu Vukotinoviću - kao odgovor na njegov članak, koji je uvodni u 45. broju »Slavenskog Juga «, u: Katolički list zagrebački 1(1849.)25, 1-7.; J. KRIŠTO, Prešućena povijest. Katolička crkva u hrvatskoj politici 1850. - 1918., Zagreb, 1994., 55-65.; M. J. MATAUŠIĆ, Odnos Katoličke Crkve prema najnovijim idejnim strujanjima u hrvatskim zemljama 1848. - 1900., u: Bogoslovska smotra 60(1985.)1-2, 196-215.; F. E. HOŠKO, Osnutak i prve godine »Zagrebačkog katoličkog lista «, u: Riječki teološki časopis 52(2018.)2, 273-288.

${ }^{2}$ Prvi predsjednik Čehoslovačke, filozof, političar i pedagog Tomaš Gariggue Masaryk 1918. godinu vidio je kao pobjedu češke reformacije nad austrijskom katoličkom monarhijom, s čime se identificirala i većina češkoga naroda koji su se odlučili pasivizirati u Katoličkoj Crkvi. Formalno su joj pripadali, ali bez prakticiranja aktivnoga vjerskoga života. Za Masaryka češki katolicizam nikad nije bio izvor narodnoga identiteta kao što je to primjerice kod Poljaka, Hrvata i Slovaka. Sam Masaryk je na vjeru gledao kao na individualnu stvar i pitanje savjesti. Masaryk se 1878. oženio sa Charlotte Garrigue i njezino je obiteljsko prezime uzeo kao svoje srednje ime. Garrigue je rođena u Brooklynu u protestantskoj obitelji, koja je među svojim predcima imala francuskih Hugenota. Rođeni katolik, Masaryk je postao protestant koji nije prakticirao vjeru. U tome je na njega uvelike utjecala dogma o papinoj nepogrešivosti iz 1870. godine i Charlotte, koja je odgajana kao unitarijanka, kao i njegov osobni pogled o slobodi vjeroispovijesti i pitanju savjesti.

${ }^{3}$ J. KRIŠTO, Liberalizam i Katolička crkva u Europi i u (Banskoj) Hrvatskoj, u: H.-G. FLECK (ur.), Liberalizam i katolicizam u Hrvatskoj, Zagreb, 1998., 46.
} 
Jugoslavije u kojoj se Crkva u Hrvata prvi put našla u državi s pravoslavnom većinom nužno je dovela do pokreta unutar same Crkve. Reformni pokret dijela nižega katoličkoga klera u Hrvatskoj razvio se ponajprije kao reakcija na nesređena socijalna i staleška pitanja unutar same Crkve, da bi u određenim fazama polako prelazio od zahtjeva za opravdanom reformom u otvoreni sukob, ideologizaciju i potpao pod političke utjecaje različitih stranaka koje su nastojale oslabiti utjecaj Crkve na hrvatsko društvo i politiku. Bio je to uglavnom politički oportunizam određenih političkih stranaka koji je doveo do propasti pokreta i kao konačnoga i jedinoga rješenja stvaranja Hrvatske starokatoličke Crkve. Kompleksnost odnosa političkih stranaka, njihovih vođa i samih osoba iz redova reformaša i predstavnika crkvene hijerarhije, kao i stanje među simpatizerima reformnoga pokreta bilo je diktirano ideološkim i političkim oportunizmom različitih političkih i društvenih subjekata Kraljevine SHS-a/Jugoslavije, koji su naposljetku doveli do toga da se na HSC počelo gledati kao na produženu ruku protuhrvatske politike beogradskih vlada. Iako je to iznimno kompleksna stvarnost i slabo istražen dio hrvatske crkvene povijesti, u ovom radu nastojat će se dati uvid u ključne procese, osobe i političke subjekte koji su polazište za daljnje istraživanje te problematike.

\section{Izolirani slučajevi reformnih pokušaja prije 1919. godine}

Među katoličkim svećenicima početkom 20. stoljeća može se na marginama događanja uočiti određene tragove liberalizma. Elemente liberalnih shvaćanja može se naći unutar Hrvatske kršćansko-socijalne stranke prava koju je osnovao Stjepan Zagorac, kasnije istaknuti reformaš i starokatolik. ${ }^{4}$ Juraj Cenkić, kasnije jedan od vođa reformnoga pokreta, 1913. godine na svećeničkom sastanku u Glogovnici predložio je veliku reformu crkvenoga financijskoga sustava koji je predviđao ukidanje lukna i parcelizaciju crkvenih imanja koja bi se podijelila seljacima. ${ }^{5}$ Snažno intelektualno i socijalno gibanje među katoličkim klerom i laikatom nije moglo nadići socijalne razlike koje su postojale unutar same crkvene strukture. U vrijeme postojanja Monarhije visoki crkveni kler i dalje je bio uključen u zamršeni zemljoposjednički i polufeudalni sustav koji je sa sobom nosio velike povlastice na svim područjima. Stanje nižega klera često je bilo sasvim drukčije.

Već u razdoblju pred Prvi svjetski rat započeli su se okupljati neki katolički svećenici na tajnim sastancima gdje su raspravljali o aktualnim crkvenim problemima i mogućnostima za njihovo rješavanje. Jedan od takvih sastanaka održan je pred Prvi

\footnotetext{
${ }^{4}$ Usp. J. GROZDEK, V. ŠAFAR, Novi pravac za Kršćansko-socijalnu stranku u Hrvatskoj, Zagreb, b. d., 5.; Program hrvatske kršć.-soc. stranke prava, Zagreb, 1906.

${ }^{5}$ Usp. A. RADIĆ, Lukno se ukida, crkvene se zemlje diele!, u: Dom (1913.)38, 1-2.
} 
svjetski rat u Rasinji, župi kojom je upravljao Stjepan Menzinger, ${ }^{6}$ kasnije jedan od pokretača reformnoga pokreta. Sastanku su prisustvovali župnici Rikard Korytnik, Stjepan Zagorac i Stjepan Haberstock.7 Svi će oni 1919. godine postati vodeće osobe reformnoga pokreta.

Za pretpostaviti je kako je izbijanje Prvoga svjetskoga rata onemogućilo daljnje razvijanje samoga pokreta, odnosno kako nije pogodovalo daljnjem nastavku razgovora o konkretnim i aktualnim pitanjima crkvene stvarnosti toga vremena. Taj prividni mir trajao je do 1917. godine, kada polako izbijaju određeni znakovi među katoličkim svećenstvom koji upozoravaju na to da među njima postoje određena previranja i nezadovoljstva u vezi s moralnim, disciplinskim, ekonomskim i socijalnim pitanjima. ${ }^{8}$ Odnosno, te iste, 1917. godine izbit će dvije afere koje potvrđuju ranije rečenu tvrdnju. $U$ prvom redu riječ je o istupu solinskoga natpopa don Nike Petrića s njegovom knjižicom Rane u Katoličkoj Crkvi i tzv. Svetokuzamskoj sinodi održanoj iste godine u mjestu Sveti Kuzam kod Bakra.

Upravo je Niko Petrić prekinuo šutnju nezadovoljnoga katoličkoga svećenstva izdajući svoju knjižicu Rane u Katoličkoj Crkvi. Knjižica je tiskana u Splitu 1917. godine. Prema njemu tri su rane koje štete Katoličkoj Crkvi: farizejstvo ili formalizam, klerikalizam i celibat. U predgovoru kaže da treba »čistu i uzvišenu Kristovu nauku što više osloboditi od ljudskog upliva i povratiti na izvornu čistoću $\ll{ }^{9}$. Prema Petriću lijek za te rane jest $\gg$ zdrav razum, te Isus Krist i njegovo Evangejelje $\ll{ }^{10}$. Petrićeva knjižica svakako sadrži niz elemenata koji će biti glavni motivacijski razlozi reformnoga pokreta, čime je on jedan od preteča reformnoga pokreta, a kasnije i njegov aktivan sudionik. Pitanja koja je otvorio svojom knjižicom, kao i njegova suspenzija i napuštanje kleričkoga staleža učinit će ga jednom od vodećih osoba reformnoga pokreta. ${ }^{11}$ Tiskanje njegove knjižice u prvom redu znači iskorak onoga

\footnotetext{
${ }^{6}$ Mentzinger se od početka zalagao za raskid s Katoličkom Crkvom i za osnivanje posebne vjerske zajednice. On je bio prvi reformni svećenik u Hrvatskoj koji je prešao na starokatoličku vjeru koja tada na teritoriju Kraljevine SHS-a nije imala ni jednu svoju župu ili kakvu drugu organizaciju. N. PETRIĆ, Uspomene iz godine 1919., u: Hrvatski katolički kalendar Grgur Ninski, Zagreb, 1939., 45.; Z. MATIJEVIĆ, Reformni pokret dijela nižega katoličkog svećenstva u Hrvatskoj (1919. 1924. god.), u: Povijesni prilozi 8(1989.), 9.

${ }^{7}$ Usp. Starokatolička crkva u Jugoslaviji, Beograd, 1960., 30.

${ }^{8}$ Usp. V. NOVAK, Magnum crimen. Pola vijeka klerikalizma u Hrvatskoj, Zagreb, 1948., 85.

${ }^{9}$ N. PETRIĆ, Rane u Katoličkoj crkvi, Split, 1917., 3-4.

${ }^{10}$ Isto, 4.

${ }^{11}$ Vladimir Vučić pisat će u Starokatoličkom glasniku 1963. kako ni Petrić ni njegova knjižica nisu utjecali na reformni pokret, kao i to da Petrić uopće nije bio aktivan u tome pokretu, dapače da je cijelo vrijeme bio pasivan sudionik te da se aktivirao tek kad je 1923. priznata Hrvatska starokatolička Crkva. V. VUČIĆ, Reformni pokret, u: Starokatolički glasnik (1963.)6., 7.; D. PATAFTA, Reformna gibanja i starokatolicizam u Dalmaciji, u: Služba Božja 58(2018. )3, 319-351.
} 
dijela nezadovoljnoga katoličkoga svećenstva koje je smatralo da je reforma Crkve nužna.

Gotovo istodobno s pojavljivanjem Petrićeve knjižice katolički svećenici Bakarskoga kotara i grada Bakra održali su 27. travnja 1917. sastanak u mjestu Sv. Kuzam iznad grada Bakra. Motivacija toga sastanka bila je isključivo socijalne naravi, za razliku od Petrićeve knjižice koja je sadržavala i određene liberalne poglede na katoličku disciplinu. Godine 1917. u Primorskim novinama objavljen je članak pod nazivom Materijalne prilike svećenstva u našem Primorju, odnosno svojevrsna deklaracija svećenika Bakarskoga kotara upućena biskupskom ordinarijatu u Senju. ${ }^{12}$ Glavni organizator i sastavljač pisma bio je trsatski župnik Andrija Rački. ${ }^{13}$ Velika ratna neimaština koja je zahvatila stanovništvo Austro-Ugarske tijekom ratnih godina odrazila se i na materijalni položaj katoličkoga svećenstva, osobito župnika i kapelana, stoga je to pismo bilo odgovor na takvo teško stanje. I u samom uvodu Primorskih novina, koje donose cjelovit tekst toga pisma, navodi se kako je »uslijed prekomjerne skupoće, koja je svuda zavladala, palo i svećenstvo našega kraja u nevolju $\ll^{14}$. Andrija Rački u Spomen-knjizi župe na Trsatu navodi kako je cilj sastanka u Sv. Kuzmi bila pravednija raspodjela crkvenih dobara čime bi se olakšao težak socijalni položaj nižega svećenstva u Primorju. ${ }^{15}$ Reakcije službenih crkvenih organa uslijedile su vrlo brzo. Biskup Josip Marušić objavio je 7. lipnja u Katoličkom listu svoju poslanicu vezanu uz zahtjeve sudionika Svetokuzamske sinode. ${ }^{16}$ Nakon toga biskup navodi niz akcija koje je poduzeo kako bi poboljšao materijalne prilike svećenstva svoje biskupije i taj prikaz završava konstatacijom kako dobri katolici nikada ne bi poduprli takav istup koji ide samo u prilog neprijateljima Crkve. $\mathrm{Na}$ kraju svoje poslanice optužuje sve potpisnike Spomenice za taštinu, umišljenu veličinu i preziranje biskupskoga autoriteta. ${ }^{17}$

Već to dovoljno govori o različitim polazištima, od kojih je Petrićevo bilo radikalno i duboko zadiralo u crkvenu disciplinu, dok je ono primorskih svećenika imalo

\footnotetext{
${ }^{12}$ Materijalne prilike svećenstva u našem Primorju, u: Primorske novine, 12. 5. 1917., 1.

${ }^{13}$ Usp. R. SKENDEROVIĆ, Andrija Rački i $\gg$ Svetokuzamska sinoda « 1917. godine, u: Riječki teološki časopis 16(2007.)2, 325.

${ }^{14}$ Materijalne prilike svećenstva u našem Primorju, 1.

${ }^{15}$ Arhiv Župe sv. Jurja Trsat (dalje: AŽJT), Spomen-knjiga župe na Trsatu, 123.

${ }^{16}$ Taj odgovor biskupa Marušića objavili su svi katolički službeni i poluslužbeni listovi: J. MARUŠIĆ, Materijalne prilike svećenstva u našem primorju, u: Službeni vjesnik biskupije senjske i modruške ili krbavske (1917.)2, 2.; J. MARUŠIĆ, Materijalne prilike svećenstva u našem primorju, u: Glasnik biskupija bosanske i srijemske (1917.)11, 82-86.; J. MARUŠIĆ, Materijalne prilike svećenstva u našem primorju, u: Katolički list (1917.)23, 265-268.

${ }^{17}$ J. MARUŠIĆ, Materijalne prilike svećenstva u našem primorju, u: Katolički list, 266.
} 
samo namjeru poboljšati njihov materijalni položaj. No ono što se može iz svega zaključiti jest činjenica da su oba ta događaja, svaki na svoj način, bila izraz nezadovoljstva nižega katoličkoga svećenstva u Hrvatskoj te nagovještaj reformnoga pokreta koji će tek uslijediti. Oni su u isto vrijeme i pokazatelj lošeg stanja toga dijela svećenstva koje je na taj način iskazalo svoje nezadovoljstvo postojećim stanjem u Crkvi u Hrvata.

\section{Reformni pokret, samostalni demokrati i slobodni zidari}

Oštar i odrješit odgovor crkvenoga vrha na Petrićevu knjižicu i Svetokuzamsku sinodu učinio je da do kraja 1917. godine više ni jedan katolički svećenik nije na takav način istupio u javnost. No ostaje neosporna činjenica da su oba ta slučaja pokazala nezadovoljstvo dijela katoličkoga svećenstva u Hrvatskoj, stoga tijekom 1918. godine u liberalno orijentiranim novinama, kao što je bila Hrvatska/Jugoslavenska njiva, izlaze nepotpisani članci ili pod pseudonimom koje su objavljivali nezadovoljni svećenici. Danas je teško utvrditi tko su bili autori tih članaka, ali za većinu se zna da je to bio tadašnji kapucin iz Rijeke o. Jeronim Dragutin Tomac. ${ }^{18}$ U ljeto 1918. godine u Župi Dekanovec u Međimurju sastala su se tri katolička svećenika: Vinko Žganec, Đuro Vilović i o. Jeronim (Dragutin Tomac). ${ }^{19}$ Raspravljali su o potrebi reforme u cijeloj Katoličkoj Crkvi, a posebno u provođenju reformi organizacije Katoličke Crkve u Hrvatskoj. Vilović i Žganec trebali su poduzeti korake oko organiziranja pokreta u sjevernoj Hrvatskoj. Glavna pitanja kojima su se bavili bilo je pitanje celibata i zavjeta čistoće kod katoličkih redovnika. Konačan rezultat dogovora bio je da svatko od njih promiče ideju reforme u svom krugu djelovanja i da se u tisku objavljuje što veći broj članaka kako bi se pridobilo i pripremilo laike i svećenike za pokret usmjeren prema reformi Katoličke Crkve. ${ }^{20}$

Pitanje celibata bilo je svakako najaktualnije. Tako su primjerice u bečkom Carevinskom vijeću češki zastupnici svećenici Jozef Stanek i Bohumil Zahradnik-Brodsky, budući vođa reformnoga pokreta u Češkoj, podnijeli interpelaciju u vezi s celibatom. ${ }^{21}$

\footnotetext{
${ }^{18}$ Hrvatski državni arhiv (dalje: HDA), Ostavština dr. Dragutina (Jeronima) Tomca, Korespondencija Tomac - Petrić, Zagreb 23. IX. 1937., kut. 2., fasc. 6.; N. PETRIĆ, Hrvatski reformni pokret. Uspomene iz godine 1918. i 1919., Hrvatski katolički kalendar Grgur Ninski, Zagreb, 1938., 44.

${ }^{19}$ Tomac je 21. VIII. 1918., koristeći se pravom na ljetni odmor, otišao iz Rijeke u Dekanovec u Međimurju, gdje je tada župnik bio Vinko Žganec (HDA, Ostavština dr. Dragutina/Jeronima/Tomca, Korespondencija Tomac - Petrić, kut. 2., fasc. 6.).

${ }^{20}$ Usp. Z. MATIJEVIĆ, U sjeni dvaju orlova, 221.

${ }^{21}$ Usp. N. PETRIĆ, Reformacija katoličkog klera, u: Jugoslavenska njiva (1919.)12, 184.; K. DOČKAL, Udio srpske crkve u češkom reformnom pokretu, Zagreb, 1942.; D. PATAFTA, Češki reformni pokret, nastanak Češke narodne crkve i uloga Srpske pravoslavne crkve na stranicama hrvatskog tiska, u: Croatica Christiana Periodica 42(2017.)80, 105-130.
} 
U Hrvatskom saboru to je učinio Stjepan Radić. ${ }^{22}$ Matijević smatra kako su između Radića i predstavnika reformnoga pokreta postojale uske veze koje su ga potaknule na njegov saborski angažman protiv celibata. ${ }^{23}$ Tomu u prilog ide i činjenica da su predstavnici nezadovoljnoga svećenstva održali potkraj 1918. godine sastanak s predstavnicima Hrvatske pučke seljačke stranke (HPSS). Sastanku su prisustvovali Stjepan Radić, Vladko Maček i Josip Predavec ${ }^{24}$ te svećenici Ante Donkovići Rikard Korytnik, član privremenoga odbora HPSS-a 1914. godine. ${ }^{25}$ Očito je da su predvodnici reformnoga pokreta tražili i političku potporu, a kao najpogodnija stranka pokazao se HPSS, već samim time što je Korytnik bio jedan od osnivača stranke, ali i zbog izraženoga antiklerikalizma Stjepana Radića. ${ }^{26}$ Osim pitanja celibata, jedan od motiva početka reformnoga pokreta bit će i pitanje položaja Katoličke Crkve u Kraljevini Srba, Hrvata i Slovenaca. Kod stvaranja nove države Južnih Slavena otvorit će se i pitanje vjerskoga ujedinjenja, odnosno reformski svećenici sve će više zahtijevati da se nadiđu barijere koje razdvajaju katolicizam i pravoslavlje, a s druge strane težit će se tomu da Crkva dobije što više narodni karakter i obilježja.

Dana 10. veljače 1919. na poziv Stjepana Menzigera i Rikarda Korytnika u Zagrebu su se sastali nezadovoljni katolički svećenici u Kraljevini SHS-u. ${ }^{27}$ Josip Gunčević navodi kako su sastanak sazvali Juraj Cenkić, Rikard Korytnik i Menzinger. ${ }^{28}$ Dok Niko Petrić spominje kako su ga sazvali Cenkić i Korytnik. ${ }^{29}$ Na sastanku se okupilo

${ }^{22}$ A. DONKOVIĆ, Stjepan Radić, u: Starokatolik (1928.)8, 1.

${ }^{23}$ Usp. Z. MATIJEVIĆ, Reformni pokret dijela nižeg katoličkog svećenstva u Hrvatskoj (1919. 1924. god.), 8.

${ }^{24}$ Maček i Predavec kasnije će stupiti u Hrvatsku starokatoličku Crkvu. Maček je pristupio starokatolicizmu jer se rastavio od prve supruge i oženio se njezinom sestrom (A. ŠKEGRO, Nadbiskup Šarić i starokatolicizam u južnom Uskoplju, u: P. JURIŠIĆ (ur.), Ivan Šarić. Vrhbosanski nadbiskup, Sarajevo, 2007., 333-334.).

${ }^{25}$ A. DONKOVIĆ, Stjepan Radić, 1. Taj susret predstavnika HPSS-a s Donkovićem i Korytnikom znak je da je Korytnik uspio pridobiti za svoje reformne ciljeve predstavnike ubrzo najjače hrvatske stranke. Sam Korytnik bio je uz braću Radić jedan od osnivača HPSS-a, stoga ni taj susret nije bio bez određene političke težine (Uspomeni Rikarda Koritnika, u: Nova Reforma 2(1919.), 11.). Kasnije će otvoreno pisati i govoriti o tome kako trebaju za svoje ciljeve pridobiti političke stranke i državu kako bi spriječili moguće biskupove progone i osigurali si jako društveno-političko zaleđe (Duhovnička smrt od Emila Mariota, u: Nova Reforma 2(1919.), 31.).

${ }^{26}$ Usp. S. BAKŠIĆ, Stjepan Radić, u: Katolički list (1928.)33, 427.

${ }^{27}$ Starokatolička crkva u Jugoslaviji, 20.; SVEĆENIK, Za slobodu mišljenja u katol. crkvi, u: Jugoslavenska njiva (1919.)22, 348.; Na okup, u: Reforma 1(1919.), 1.

${ }^{28}$ J. GUNČEVIĆ, Godišnjica pokreta nižeg klera u Jugoslaviji I., u: Glasnik biskupija bosanske i srijemske (1920.)3-4, 12.

${ }^{29}$ N. PETRIĆ, Uspomene iz reformnog pokreta, 45. 
oko 20 do 25 svećenika. ${ }^{30}$ Uglavnom su to bili mlađi svećenici i kapelani. ${ }^{31}$ Glavnu riječ vodili su Korytnik, ${ }^{32}$ Cenkić, Menziger, ${ }^{33}$ Stjepan Haberstock i Stjepan Horvat. Cilj sastanka bio je da se od crkvenih vlasti zatraži rješavanje »socijalnih nepravdi koje pritišću niži kler «. ${ }^{34}$ Tekst te rezolucije bit će objavljen u knjižici Savremene želje katoličkog nižeg klera države SHS tiskane u Bjelovaru 1919. godine. Autorstvo rezolucije i izjave obično se pripisuju Cenkiću, Korytniku ili Menzigeru, ${ }^{35}$ iako Matijević smatra da je njezin konačan oblik rezultat kolektivnoga rada reformnih svećenika iz užega odbora izabranoga na zagrebačkom sastanku 10. veljače. ${ }^{36}$ Kako su korice knjižice bile žute boje, a sama knjižica predstavljala je temeljni dokument organiziranja i djelovanja reformnoga pokreta, cijeli pokret nazvan je žutim pokretom.

Osnivanje nove države Kraljevine SHS-a podržali su članovi Seniorata, kao vodstvo Hrvatskoga katoličkoga pokreta (HKP), i cijeli hrvatski episkopat, izuzev vrhbosanskoga nadbiskupa Josipa Stadlera, koji je u prosincu 1918. umro. Vjersko pitanje bilo je iznimno važno za novonastalu državu te je već u prosincu 1918.

${ }^{30}$ Petrić navodi brojku od 20 svećenika (N. PETRIĆ, Uspomene iz reformnog pokreta, 45.), dok Gunčević navodi brojku od 25 svećenika (J. GUNČEVIĆ, Godišnjica pokreta nižeg klera u Jugoslaviji I., 12.).

${ }^{31}$ JEDAN SVEĆENIK VRHBOSANSKI, Crkveni celibat, u: Vrhbosna (1919.)7-9, 76.

32 Rikard Korytnik vrlo brzo nakon zagrebačkoga sastanka umire, 9. travnja 1919. Usp. Uspomeni Rikarda Koritnika, 10-12.

${ }^{33}$ Stjepan Menziger prvi je svećenik član reformnoga pokreta koji je pristupio Starokatoličkoj Crkvi koja do tada na cijelom području Kraljevine SHS-a nije ni postojala. Petrić u svojim sjećanjima donosi dio iz pisma koje mu je iz Pančeva, gdje je bio nastavnik, poslao Menziger: »Da li poznajete moje ime, to neznam, nu da smo na istom bojnom polju to ćete saznati iz slijedećih redaka. Moje četverogodišnje svećeničko službovanje dovelo me je do spoznaje, da je taj stalež pun u nebo kričućih sablasti i perfektan farizejizam. Oslobođenje je moje došlo oslobođenjem otadžbine. Ostavio sam svećeničku službu i apsolvirao sam filozofiju. Tvrdo sam uvjeren, da mi u borbi protiv celibata legalnim putem ne možemo postići nikakav uspjeh. Katolička crkva imade duh imperijalistički, koji je u nju ucijepio sv. Augustin sa svojim 'Civitas Dei'. Taj će božji grad biti tada, kada će na mjesto civilnog klera zavladati redovnički, što neosporno opažamo na svim linijama katoličke administracije. Borba je naša ne sa papom i crkvom, već sa fratrima i drugim parasitima socijalnog poretka, kojima kao takovima konvenira današnja hierarhija i organizacija katoličke crkve. nama ne preostaje drugo, već se prilagoditi toj organizaciji ili segnuti za drugom. Ta druga bila bi po mom uvjerenju Starokatolička Crkva, koja tačno odgovara našim pravednim zahtjevima. Ona je katolička, ali nije imperijalistička, ona je iskrena, narodna, ona mora biti prava. zaista! Hrvatski narod nije od Rima ništa primio, već svoju narodnu propast kroz stotine godina. taj narod može i mora reći: 'Los vom Rom' - To je nesumnjivo.« (N. PETRIĆ, Hrvatski reformni pokret. Uspomene iz godine 1919., 45.)

${ }^{34}$ Starokatolička crkva u Jugoslaviji, 20.

${ }^{35}$ V. VUČIĆ, Reformni pokret, 6.; Starokatolička crkva u Jugoslaviji, 20.

${ }^{36}$ Usp. Z. MATIJEVIĆ, Reformni pokret dijela nižeg katoličkog svećenstva u Hrvatskoj (1919. 1924. god.), 10.; Z. MATIJEVIĆ, U sjeni dvaju orlova, 224. 
formirano Ministarstvo vjera, koje je postalo nadležno za sva pitanja iz područja religijsko-političkoga života. U Kraljevini SHS-u država i religija djelomično su se odvojile. Iako nije više postojala institucija državne Crkve, nije provedena ni potpuna laicizacija države, jer to nije bilo u interesu vladajućih elita, osobito zbog snažnoga utjecaja vjerskih institucija na vjernike, odnosno biračko tijelo. ${ }^{37} \mathrm{Bez}$ obzira na to što su gotovo svi relevantni predstavnici Katoličke Crkve u Hrvatskoj podržali osnivanje južnoslavenske države, već početkom 1919. godine zaoštrili su se odnosi $\mathrm{u}$ pitanju ingerencije nad sustavima odgoja i obrazovanja. ${ }^{38} \mathrm{~S}$ vremenom se otvorio niz problema koji će početi opterećivati odnose Katoličke Crkve i države. Od onih ključnih to je bilo već spomenuto pitanje ingerencije nad sustavom odgoja i obrazovanja, gdje se Crkva suočila s nasilnom sekularizacijom i pokušajem potpune laicizacije sustava, i pitanje potpisivanja konkordata. Umjesto dotad relativno umjerenoga liberalizma Crkva se u novoj državi susrela s netolerantnim sekularizmom s ciljem potpune marginalizacije svih religijskih uvjerenja građana i svođenja na privatnu sferu.

U iznimno složenim vjerskim i političkim pitanjima u novonastaloj državi uvijek je u pozadini ostajala snažna uloga slobodnoga zidarstva koje je upravo postalo jedan od čimbenika u oblikovanju odnosa države prema Katoličkoj Crkvi. Dominantna politička stranka prvih godina postojanja Kraljevine SHS-a bila je Samostalna demokratska stranka Svetozara Pribićevića. Na snažan utjecaj slobodnih zidara upravo u toj stranci upozorio je 1958. godine Jovan Marjanović, koji u svome članku piše sljedeće: $\gg$ Najzad na Demokratsku stranku je vršila određeni utjecaj i masonerija, čiji su mnogi članovi bili funkcioneri Demokratske stranke, povezani preko masonske lože s raznim zapadnim zemljama. ${ }^{39}$

Stanje u Crkvi u Hrvata u vrijeme pojave reformnoga pokreta opisuje u svojim sjećanjima Ljuboslav Kuntarić st., istaknuti sudionik HKP-a, koji kaže kako je pojavi žutoga pokreta prvotni uzrok bio »vrlo kruti konzervativni institucionalizam « naslijeđen iz vremena Monarhije. ${ }^{40}$ Kuntarić u svojim sjećanjima navodi na primjeru Međimurja kako su pod utjecajem Ivana Novaka, slobodnoga zidara, prodrle liberalne ideje među dio međimurskoga svećenstva, a kojega su podupirali Pribićevićevi samostalni demokrati. Navodi kako su »od vjere otpali dr. Vinko Žganec, Šafarić,

${ }^{37}$ Usp. I. HRSTIĆ, Vrijeme promjena - Makarska 1918. - 1929., Zagreb, 2016., 392.

${ }^{38}$ Usp. Z. MATIJEVIĆ, Katolička crkva u Hrvatskoj i stvaranje jugoslavenske države 1918. - 1921., u: Povijesni prilozi 5(1986.)1, 1-93.

${ }^{39}$ J. MARJANOVIĆ, Političke partije Kraljevine Srba, Hrvata i Slovenaca (1921. - 1929.), u: Iz istorije Jugoslavije 1918. - 1945., Beograd, 1958.

${ }^{40}$ Arhiv franjevačkog samostana u Našicama (dalje: AFSN), Ljuboslav KUNTARĆ, Bilješke o prilikama u Katoličkom pokretu poslije 1918. godine, B-XVI-46-13, 6. 
Juraj Lajtman, dr. Vidušić, Djuka Vilović. Njima su samostalni demokrati osigurali ekistenciju. Tako je framazun I. Novak uspio pocijepati katoličko svećenstvo preko jedne političke stranke $\ll^{41}$. Kuntarić nadalje piše kako je vjenčanje Vinka Žganca u Dekanovcu izazvalo negodovanje puka koji je protestno napustio crkvu. ${ }^{42}$ Nadalje u svojim sjećanjima bilježi osnivanje HPSS-a i Hrvatske pučke stranke (HPS) u Međimurju kao i njihove prve sukobe. Konstatira kako je pobjedi HPSS-a/HRSSa na izborima 1921. godine pridonio nejasan socijalni program i loša nacionalna politika HPS-a te da je »pobjedom Hrvatske seljačke republikanske stranke odredjena linija hrvatske politike do 1941. god. ${ }^{43}$

Reformni svećenici dobili su podršku od liberalnih listova u Hrvatskoj. Riječ SHS, glasilo Pribićević-Davidovićeve Demokratske stranke, u sažetom članku donosi smjernice djelovanja reformnoga pokreta naglašavajući kako »niži katolički kler ide za nizom vanjskih reforma katoličke crkve u Jugoslaviji a da ne dira u članke katoličke vjere $s$ ciljem da provedu reformu katoličke crkve u našim krajevima u duhu modernog vremena $\ll^{44}$. Autor članka ističe još jedan segment djelovanja reformnoga pokreta, a koji je uvijek nekako bio po strani iako je istaknut i u samim Savremenim željama, a to je rad na zbližavanju istočne i zapadne Crkve. Autori Savremenih želja navode kako je celibat glavna prepreka ujedinjenju Crkava, zato i zagovaraju njegovo ukidanje kako bi, prema njima, nestalo glavne prepreke u odnosima dviju Crkava te izražavaju duboko uvjerenje da »će se konačno latinska crkva s istočnom izmiriti baš na Balkanu $\ll{ }^{45}$. Ta nacionalno-religijska komponenta reformnoga pokreta uvijek je ostajala po strani svakoga govora o tome pokretu, dok je s druge strane činila jedno od središnjih pitanja cijeloga njegova djelovanja. Pitanje celibata koje su reformni svećenici stavljali dugo u prvi plan nije bilo samo pitanje promjene katoličke discipline nego i pitanje uklanjanja prepreka prema pravoslavlju. No taj način razmišljanja ponovno treba promisliti u kontekstu liberalnih idejnih strujanja koja su dugo dominirala hrvatskom društvenom i političkom scenom u vremenu neposredno nakon ujedinjenja, kada se nastojalo što više učvrstiti postignuto jedinstvo u novoj državi. Učvršćivanje toga jedinstva nije počivalo samo na liberalnim shvaćanjima jedinstva zajedničke države na temelju ravnopravnosti svih triju naroda nego se odražavalo i na religijskom planu u pokušajima približavanja katolicizma pravoslavlju. Taj zahtjev očitovao se i u želji da se u katoličko bogoslužje u Hrvatskoj uvede narodni jezik, odnosno da se povlastica služenja staroslavenske službe Božje protegne na čitavu

\footnotetext{
${ }^{41}$ Isto, 4-5.

${ }^{42}$ Isto, 8.

${ }^{43}$ Isto, 9-12.

${ }^{44}$ Pokret nižeg hrvatskog klera, u: Riječ SHS (1919.)239, 3.

${ }^{45}$ Savremene želje katoličkog nižeg klera u državi SHS, Bjelovar, 1919., 23.
} 
Crkvu u Hrvata, kao svojevrsni most prema pravoslavlju. I u tome su reformni svećenici nailazili na podršku liberalnoga javnoga mnijenja. ${ }^{46}$

Iako je sam pokret bio unutarnje reformno gibanje u Katoličkoj Crkvi u Hrvatskoj, ponekad je bio dovođen i u vezu sa slobodnim zidarima. Za sada je nemoguće dokazati jesu li vodeći ljudi reformnoga pokreta bili izravno povezani sa slobodnim zidarima, ali su svakako uživali njihovu veliku podršku. Primjerice o. Petar Grabić uspoređuje reformni program Stjepana Zagorca, vodećega reformaša, s idejama poznatoga slobodnoga zidara Milana Marjanovića, ${ }^{47}$ za kojega kaže da $\gg$ neće da znade za kršćansko, ni za katoličanstvo $(. ..) \ll^{48}$. Donošenje Vidovdanskoga ustava 28. lipnja 1921. godine, pri čemu su vodeću ulogu imali Pribićević i njegova Demokratska stranka, dovelo je do toga da se hrvatska liberalna javnost svrstala uz oporbeni blok predvođen Stjepanom Radićem. Zbog veza reformnoga pokreta sa zemaljskom vladom u Hrvatskoj i središnjom vladom u Beogradu, kao i zbog otvorene naklonosti Pribićevića i njegovih demokrata, liberalni je tisak počeo promatrati reformni pokret kao svojevrstan eksponent protuhrvatske politike. ${ }^{49} \mathrm{Naj}$ zornije to svjedoči članak vodećega liberalnoga glasila Obzor, koje je sve do tada simpatiziralo pokret, a zatim piše sljedeće:

$\gg$ Ovaj pokret podupiran je od prvog časa od demokrata i to naročito onih, kojima nije stalo do hrvatstva ni do hrvatskog bogoslužja, prvo zato jer su Jugoslaveni a ne više Hrvati, a drugo zato jer su antiklerikalci, pa im je posve svejedno da li se uopće čita kakova misa. Ti demokrati najjače podupiru taj pokret, jer misle da će tim pokretom oslabiti i Hrvatstvo i katolicizam, a tim ojačati indirekte pravoslavlje, protiv koga nemaju ništa, mada je pravoslavlje kud i kamo 'klerikalnije' nego je katolicizam. Naravno ti demokrati i katolički antiklerikalci tvrde da smo svi mi Srbi i Hrvati jedan narod, ali da mi Hrvati imademo tuđu vjeru i Talijana za vjerskog poglavicu, a da je pravoslavna crkva skroz nacionalna 'srpska' (...). Naročito su demokrati išli za tim da oslabe upliv katoličke crkve i njenu snagu podupirući svaki pokret protiv katoličke crkve... Zar ti reformisti ne vide za čim se ide? Zar ne vide da su samo orudje demokrata, koji hoće da i na taj način pospješe 'asimilaciju' Hrvata. Mi smo zaista odlučni protivnici svakog ultramontanstva i klerikalizma... No kad vidimo da se vjera upo-

${ }^{46}$ Osječki katolici za slavensko bogoslužje, u: Riječ SHS (1919.)241, 3.; Pokret kat. nižeg klera u državi SHS, u: Obzor, 20. 5. 1919., 2.

${ }^{47}$ Usp. M. MARJANOVIĆ, Smjernice obnove naroda, Zagreb, 1919.

${ }^{48}$ P. GRABIĆ, Unija crkvi i reformno svećenstvo, u: Katolički list (1920.)32, 336.

${ }^{49}$ Z. MATIJEVIĆ, U sjeni dvaju orlova, 261.; D. PATAFTA, Hrvatski liberalni tisak o reformnom pokretu dijela katoličkog nižeg klera (1918. - 1923.), u: Pilar 11(2017.)1, 11-44. 
trebljuje u političke svrhe i da se navaljuje na katolicizam, jer ga ispovijedaju Hrvati i Slovenci, onda mi (...) branimo... instituciju. Dopuštamo, da ti reformni svećenici rade bona fide, no njihov je rad i logički i psihološki jedna zabluda (...). Nesumnjivo će Hrvati odbiti ovaj politički pokret, koji pod krinkom nacijonalnog hrvatstva, faktično slabi hrvatstvo. A onima koji to podupiru i inspiriraju preporučujemo, da je ovaj ref. pokret sasma loše sredstvo da se Hrvate prevede u pravoslavlje. $\ll^{50}$

Nakon donošenja Vidovdanskoga ustava reformni pokret podržavali su još jedino Pribićevićevi slobodni demokrati pod snažnim utjecajem slobodnih zidara i jedini medijski prostor dobivali su u tiskovinama koje su iznosile slobodnozidarske ideje i bile bliske samostalnim demokratima, kao što su Slobodna Tribuna i Riječ SHS. Da su slobodni zidari bili podupiratelji širenja reformnoga pokreta, a kasnije i starokatolicizma, potvrđuje u svojoj knjizi Slobodnozidarska čitanka beogradski slobodni zidar i veliki meštar lože Jugoslavija Vojislav Kujundžić koji piše: »Kad smo olako prenebegli ona dva ranija pokreta protiv Rima, negujmo, propagirajmo, agitujmo i širimo Staro-Katoličku Crkvu (...). $\ll^{51}$

Da su članovi slobodnozidarskih društava bili usko povezani s vladajućim krugovima u Beogradu, osobito s Pribićevićevom Samostalnom demokratskom strankom, svjedoči i poprilično banalan primjer kako je odredbom Ministarstva prometa članovima Velike lože Jugoslavije dopušteno uz predočenje iskaznice lože putovati vlakom u pola cijene. ${ }^{52}$ Stjepan Bakšić, govoreći o važnosti katoličkoga tiska, dovodi u usku vezu slobodnozidarske lože s vladama Pribićevićevih demokrata i srpskih radikala. On slobodnozidarske lože naziva »vrutkom protukršćanske agitacije « i veliku važnost otporu slobodnozidarskim idejama vidi u jačanju katoličkoga tiska kako bi uspješnije parirali ciljevima slobodnih zidara koje oni programiraju i ostvaruju pomoću tiska. ${ }^{53}$

Na Sušaku je u gradskoj vijećnici 26. srpnja 1919. na poticaj Nike Petrića osnovano društvo Reformator kako bi potpomagalo svećenike koji stradavaju u sukobu s episkopatom zbog svojih reformnih ideja i potpomaganja časopisa Reforma ${ }^{54} \mathrm{Na}$ sastanku je pročitan proglas koji su objavile Primorske novine ${ }^{55}$ i izabran je Promi-

\footnotetext{
${ }^{50}$ Reformni kler, u: Obzor 62(1921.)355, 3.

${ }^{51}$ V. KUJUNDŽIĆ, Slobodno-zidarska čitanka, Beograd, 1940., 122.

${ }^{52}$ Velika Loža državna institucija, u: Katolički list (1921.)7, 79.

${ }^{53}$ Usp. S. BAKŠIĆ, Za katoličku štampu, u: Katolički list (1924.)26, 305.

${ }^{54}$ Reformator. Društvo za potporu svećenika liberalnog nazivanja i za potpomaganje njihova glasila $\gg$ Reforma « zvanog, u: Nova Reforma 2(1919.), 36.

${ }^{55}$ Jugoslavenski narode!, u: Primorske novine, 31. 7. 1919., 1.
} 
cateljni odbor koji su činili Gjivo Supilo, odvjetnik i nećak Frana Supila, Andro Knez, općinski bilježnik i kasnije ministar, Niko Petrić, novinar i pravnik Maksim Mrzljak, Peroslav Ljubić, vlasnik i urednik Primorskih novina, Srećko Kovačević, trgovac i posjednik, Ivo Brgić, Vladimir Dečak, odvjetnik Ante Kraljić, pravnik Ivan Krzmarić i Mate Kević. ${ }^{56}$ Očito je da je uz reformni pokret na Sušaku pristao onaj dio građanstva koji je s obzirom na svoje zvanje i društveni položaj bio uglavnom liberalno orijentiran. Ne čudi i uključivanje Peroslava Ljubića koji je u Primorskim novinama od samih početaka pokazivao neskrivene simpatije za reformni pokret, ali i stvarao društvenu klimu koja će taj pokret poduprijeti. Naime Ljubić kroz cijelu 1919. godinu izdaje niz članaka u kojima napada tobožnju rimsku protalijansku politiku po pitanju Rijeke. ${ }^{57}$ Proglas društva Reformator na tome je tragu sadržavao mnoge elemente koji su išli mnogo dalje od reforme i polagano zagovarali raskol, osobito u dijelu u kojem kažu sljedeće:

>Mi kao Jugoslaveni veselimo se i rado podupiremo svaki onaj pokret, koji ide za blagostanjem naše mlade države. Pokret našeg nižeg kat. svećenstva ne samo što je kulturnog, već je i političkog značenja. Taj pokret ne samo što priznaje jedinstvo našeg troimenog naroda, već ide za njegovim vjerskim ujedinjenjem. To je ono što nas u velike veseli, jer uvjereni smo dokle god ne budemo vjerski ujedinjeni i dokle god ne budemo imali našu narodnu crkvu, da će uvijek izmedju nas biti trzavica koje će uglavnom dolaziti iz latinskog Rima, a preko našeg višeg klera. sa današnjim našim višim klerom, koji je rekrutiran po kriterijima Beča i Rima, mi Jugoslaveni nećemo moći ništa učiniti. ${ }^{58}$

U tom slučaju zamjetna je jedna novost koja će dovesti do toga da će se reformni pokret $s$ vremenom sve više radikalizirati, a to je ulaženje svjetovnjaka u reformni pokret, što je učinjeno prvi put osnivanjem Reformatora na Sušaku. Na osnivanje

\footnotetext{
${ }^{56}$ Reformator. Društvo za potporu svećenika liberalnog nazivanja i za potpomaganje njihova glasila $\gg$ Reforma $\ll$ zvanog, 36.

${ }^{57}$ Češko svećenstvo i naše, u: Primorske novine, 24. 6. 1919., 2.; Naši odnošaji prema Rimu, u: Primorske novine, 26. 6. 1919., 3.; Braniteljima Vatikana, u: Primorske novine, 5. 7. 1919., 2.; Moderni pokret medju jugoslavenskim katoličkim klerom, u: Primorske novine, 13. 7. 1919., 2-3.; Braniteljima Vatikana, u: Primorske novine, 24. 7. 1919., 1.; Braniteljima Vatikana, u: Primorske novine, 25.7. 1919., 1-2.; Braniteljima Vatikana, u: Primorske novine, 26. 7. 1919., 1-2.; Braniteljima Vatikana, u: Primorske novine, 27. 7. 1919., 1-2.; Vatikan i Jugosloveni, u: Primorske novine, 30. 6. 1919., 1-2.

${ }^{58}$ Jugoslavenski narode!, 1.; taj tekst proglasa društva Reformator pročitao je i o. Jeronim Tomac, tada još riječki kapucin, koji je uz tekst ostavio neke bilješke među kojima i onu u kojoj se ne slaže sa stvaranjem zasebne Crkve neovisne o papi i crkvenoj hijerarhiji. On je uglavnom kao i većina svećenika pristalica i simpatizera reformnoga pokreta zastupao ideju reforme Katoličke Crkve u Hrvatskoj, a ne raskid s Rimom (HDA, Ostavština dra. Tomca, kut. 1., fasc. 4.).
} 
društva Reformator ponovno su se oborila katolička glasila. Najoštrije ju je napadao Petar Rogulja ${ }^{59} \mathrm{u}$ Narodnoj politici. Rogulja prvi spominje razliku između reformnoga pokreta kao pokreta katoličkoga svećenstva i navodi da u državi ima preko 1500 pristalica, dok je Reformator laičko udruženje koje podupire reformni pokret svećenstva. ${ }^{60}$

Skupina oko Nike Petrića u svojim je zahtjevima bila krajnje radikalna, a okupljala je i laike oko društva Reformator. Smatrala je da je jedini način da se provedu reforme napuštanje Katoličke Crkve. Odnosno, to je značilo osnivanje posebne hrvatske autokefalne zajednice $s$ vlastitim ustavom, hijerarhijom i cjelokupnom crkvenom organizacijom. ${ }^{61}$ Toj skupini oko Petrića uglavnom su pripadali liberalni građani neovisni o Crkvi i time u svojim zahtjevima radikalniji u provođenju reformi, pa i pod cijenu raskola.

Nakon propasti pokušaja provođenja reforme u Koprivnici tijekom 1921. godine ${ }^{62}$ i pošto su izgubili službe u Crkvi, Stjepan Zagorac i Stjepan Vidušić odlaze u Beograd s namjerom da upoznaju vladu s idejama reformnoga pokreta. Tu su navodno dobili podršku Svetozara Pribićevića, predsjednika Samostalne demokratske stranke, čije su novine u Hrvatskoj davale veliki prostor u svojim izdanjima reformnom pokretu. Nije poznato kakva su obećanja dobili, no činjenica je da su očito bili dovoljno ohrabreni da zaposjednu koprivničku župu i otjeraju Jurja Špoljara. Zagorac se kasnije tužio kako ga je nuncij u Beogradu oklevetao kod ministra vjera Pavla Marinkovića da je plaćenik slobodnih zidara. ${ }^{63}$ Katolički list bilježi kako su jamstva koja je Zagorac dobio od Pribićevića bila poticaj za njegov siloviti čin u Koprivnici. Članak zaključuje sljedećim riječima: »dvije su stvari začudne. Prva je, da Zagorac, idejni pristaša Radićev, traži zaštitu kod centralističkog ministra demokrate, a druga je, da centralistički ministar obećaje pomoć sljedbeniku Radićevu. ${ }^{64}$ Narodna politika također pripisuje Zagorčev čin jamstvima koja mu je dao Svetozar Pribićević. ${ }^{65}$ Da su Pribićevićeva jamstva djelovala na Zagorca svjedoči i činjenica da je Zagorac od šefa policije tražio pratnju kako bi oduzeo ključeve crkve i župne kuće

${ }^{59}$ J. KRIŠTO, Petra Rogulja i razvoj Hrvatskog katoličkog pokreta, u: Croatica Christiana Periodica 25(2001.)47, 207-223.

${ }^{60}$ P. ROGULJA, Demokrati hoće da pooštre svoj kulturkampf, u: Narodna politika (1919.)191, 3.

${ }^{61}$ Isto, 47-48.

${ }^{62}$ Usp. D. PATAFTA, Reformni pokret i starokatolicizam u Koprivnici, u: Podravina 15(2016.)30, 174-198.

${ }^{63}$ S. ZAGORAC, Narodna crkva i katolicizam, Zagreb, 1925., 14-15.; Koprivničko pitanje i vlada, u: Katolički list (1920.)25, 195.; Siloviti čini »reformaša «, u: Narodna politika, 20. 7. 1920., 3.

${ }^{64}$ Koprivničko pitanje i vlada, 196.

${ }^{65}$ Siloviti čini $\gg$ reformaša $\ll, 3$. 
upravitelju Špoljaru. ${ }^{66}$ U prilog tomu da je Zagorac uživao veliku Pribićevićevu potporu govori i to da se njegov pokret počeo nazivati pokretom za Pribićevićevu cr$k v u \cdot{ }^{67}$ Glasilo Demokratske stranke Demokrat koje se tiskalo u Koprivnici otvoreno je iskazivalo simpatije za reformni pokret: $\gg$ sa najvećom simpatijom pratimo ovaj pokret narodnih svećenika, pokret koji je radi svog velikog i kulturnog narodnog značenja svake potpore vrijedan. $\ll^{68} \mathrm{I}$ kod suspenzije Zagorca Demokrat zauzima njegovu stranu: »naprotiv naš će župnik ostati pa ma se i cijeli Kaptol na glavu postavio. $\ll{ }^{69}$ Narodna politika napada reformne svećenike kao Pribićevićeve eksponente i piše sljedeće:

»Nakon bivšeg franjevca Miloševića i bivšeg radićevca Zagorca dolazi na čelo žutog pokreta Danuncijev čestitar i bivši kapucin Dragutin Tomac. Kao što se Pribićevićeva 'Riječ' zauzimala prije za Miloševiće, tako se sada zauzima za Tomca. Stvar je ista, samo se firma promijenila. 'Demokratima' je potrebna Pribićevićeva crkva, oni bi htjeli da se pomoću nje nametnu narodu koji ih je odbacio. Zato su poslali najprije u borbu Miloševića, kasnije Miloševića zamijenili sa Zagorcem, a sada misle da su našli svoga borca u signoru Tomcu. Ni on nema ni moralnih ni političkih za to da osnuje Pribićevićevu crkvu. $\ll^{70}$

Vodstvo reformnoga pokreta na čelu sa Zagorcem u siječnju 1921. preselilo je djelovanje pokreta iz Koprivnice u Zagreb. Nakon ekskomunikacije svih članova reformnoga pokreta koji su prisustvovali misi na hrvatskom jeziku u Zagrebu, raskol je bio očit. Reformaši su nastojali legalizirati svoj položaj kao zasebna vjerska zajednica, međutim to im nije uspijevalo zbog odredaba članka 12. Vidovdanskoga ustava o vjerskim zajednicama u Kraljevini SHS-u. Nadbiskup Bauer dobio je od ministra vjera Ivana Krstelja uvjerljivo pismo kako vladi nije u interesu podupirati reformni pokret. Biskupi s područja Kraljevine SHS-a odlučili su se obratiti na najvišu državnu instanciju kako bi potpuno onemogućili potporu koju su ban Juraj Demetrović, član Pribićevićeve stranke i slobodni zidar, kao i njegov podban Franko Potočnjak ${ }^{71}$ pružali reformnom pokretu i njihov otpor prema Bauerovim i

\footnotetext{
${ }^{66}$ Iz glavnog stana $\gg$ žutog pokreta «, u: Narodna politika, 24. 7. 1920., 3.

${ }^{67}$ Žuti osnivaju Pribićevićevu crkvu, u: Narodna politika, 18. 8. 1920., 2.

${ }^{68}$ Svećenički žuti pokret, u: Demokrat, 4. 7. 1920., 2.

${ }^{69}$ Reformni pokret i natječaj za koprivničku župu, u: Demokrat, 18. 7. 1920., 3.

${ }^{70}$ Osnivači Pribićevićeve crkve, u: Narodna politika, 22. 8. 1920., 3.

${ }^{71}$ Juraj Demetrović primljen je u ložu Maksimilijan Vrhovac u Zagrebu 2. prosinca 1918., dok je Franko Potočnjak predratni slobodni zidar primljen u masonsku ložu u Budimpešti 1908. godine. M. GLOJNARIĆ, Masonerija u Hrvatskoj, Zagreb, 1942.; Potočnjak je napisao i tri protukatolička spisa: F. POTOČNJAK, Hrvatska akcija po receptu Rima i Beča, Zagreb, 1901., ISTI, Pogledi na klerika-
} 
Krsteljevim nastojanjima da se suzbije reformni pokret. Vezano uz reformni pokret biskupi u Predstavci navode sljedeće:

»Od kat. Crkve otpali svećenici, koji dižu formalnu bunu u kat. Crkvi, uživali su u Hrvatskoj sasvim očitu potporu pokrajinske vlade. To se može shvatiti samo tako, da vlada nalazi svoj interes u tome pokretu, a to opet znači, da vlada očekuje neke probitke za sebe, ako se u kat. Crkvi podupiru smutnje, ako se ona oslabi. Rado priznajemo istinu, da smo od centralne vlade u Beogradu već ponovno primili protivna uvjerenja, dapače i protivne odredbe osobito u najnovije vrijeme. Ali do danas se ne opaža u praksi ništa od toga i ako dalje tako ostane, moramo doći do uvjerenja, da nekome više vrijedi rovarenje desetak otpalih svećenika, bez ikakve religiozne ideje, nego li Crkva katolička. ${ }^{72}$

Demetrović nije samo tolerirao i podupirao rad reformnih svećenika i njihova pokreta, dapače, nastojao je uvjeriti ministra Krstelja kako je prema pravno-političkim argumentima njegovo shvaćanje članka 12. Vidovdanskoga ustava prema reformnom pokretu pogrješno. U prilog tomu išao je i zaključak državnoga nadodvjetništva u Zagrebu koje je, kao nadležna institucija za tumačenje kaznenih djela i ogrješenja o državne zakone, zauzelo stav o posvemašnjoj kaznenoj neodgovornosti reformnog pokreta s obzirom na njihove pretenzije provođenja reforme $\mathrm{u}$ Katoličkoj Crkvi. ${ }^{73}$ Demetroviću s vremenom nije preostalo drugo nego da se pokori višim organima vlasti.

Reformni pokret pokušao se proširiti i izvan Zagreba uz pomoć samostalnih demokrata. Misa na hrvatskom jeziku bit će održana i u Sisku u prostorima Velikog kaptola 29. listopada, i to u organizaciji tamošnjih članova Demokratske stranke. Taj slučaj potaknut će Narodnu politiku da to prokomentira na sljedeći način:

»Već dulje vremena pripravljao im je teren ovdašnji listić, sada glasilo demokratske stranke, koji je pozvao otpadnike, da afirmiraju 'hrvatsku' stvar... Misu je oglasio organ demokratske stranke... Čudno je, dok demokrati s jedne strane ukidaju hrvatske nazive, ovdje se sad najednom

lizam u Hrvatskoj, Zagreb, 1903.; ISTI, Malo istine iz naše nedavne prošlosti, Zagreb, 1921.; u svojim člancima otvoreno je zastupao slobodnozidarske ideje i isticao ulogu slobodnih zidara u stvaranju Kraljevine SHS-a/Jugoslavije: ISTI, Kako izgledaju kubni blokovi koje su srpski masoni prinijeli u temelje ujedinjenja Srba, Hrvata i Slovenaca, u: Obzor (1928.)59, 28., ISTI, Slobodni zidari Hrvati u radu za narodno naše ujedinjenje i oslobodjenje u vrijeme rata, u: Šestar 1(1921.)4, 29.

${ }^{72}$ Predstavka jugosl. katoličkog episkopata o nepravdama protiv kat. Crkve u Jugoslaviji, u: Katolički list (1922.)18, 211; Vlada prema katoličkoj crkvi, u: Narodna politika, 5. 5. 1922., 3.

${ }^{73}$ V. NOVAK, Magnum crimen, 184-185. 
u demokratskom listiću agitira za 'hrv. katolički pokret' i žarki hrvatski patriotizam. $\ll^{74}$

Prema pisanju Narodne politike upravo je ta uska povezanost reformaša i demokrata u Sisku dovela do toga da se pokret nije uspio nimalo proširiti među stanovništvom. ${ }^{75}$ Bez obzira na djelovanje nadbiskupa Bauera i ministra vjera Krstelja, reformni se pokret tijekom 1922. počeo značajnije širiti, ponajprije zahvaljujući neskrivenoj potpori Jurja Demetrovića i Samostalne demokratske stranke, koji su na pokret gledali s neskrivenom simpatijom i otvorenom potporom. Osnivanje hrvatsko-katoličke župe u Zagrebu, prve takve institucije reformnoga pokreta neovisne o Katoličkoj Crkvi, predstavlja trenutak razgraničenja u reformnom pokretu, svojevrsni međaš. Upravo je taj čin udario temelje organiziranju nove vjerske zajednice reformnih svećenika koja će 1923. godine prerasti u Hrvatsku starokatoličku Crkvu (HSC) i kao takva dobiti priznanje od države. Neuspješna borba za legalizaciju reformnoga pokreta kroz 1922. godinu svoje će ostvarenje dobiti u osnivanju HSC-a. Godina 1922. razdjelnica je u tijeku reformnoga pokreta koji se sve više udaljava od Katoličke Crkve i postaje zasebna stvarnost koja se usmjerava prema definitivnom raskolu.

Naredbom ministra vjera Ljube (Ljubomira) Jovanovića, osobnoga prijatelja nuncija Ermenegilda Pellegrinettija, Hrvatsko-katolička Crkva (HKC), kako su se nazvali reformaši, i cijeli pokret našli su se izvan zakona. Kako bi pronašli izlaz, Marko Kalogjerá i Stjepan Vidušić borave u Beogradu od 19. do 27. travnja 1923. i vode pregovore $s$ ministrom Jovanovićem. ${ }^{76}$ Rezultati tih pregovora nisu poznati, no zamjetno je kako je već 15 . svibnja održan sabor vođa reformnoga pokreta na kojem je ime HKC-a izmijenjeno u Hrvatsko-katolička prvodobna Crkva. ${ }^{77} \mathrm{Ne}-$ mogućnost da se HKC legalizira i nova ministrova naredba prisilili su vođe reformnoga pokreta da pronađu rješenje kojim bi dobili dugo traženu legalizaciju. $\mathrm{Na}$ čelo pokreta stao je tada Marko Kalogjerá koji je predložio da HKC prijeđe na starokatolicizam. ${ }^{78}$ Početkom studenoga Stjepan Vidušić i Ferdo Šišić, član zagrebačke slobodnozidarske lože, ${ }^{79}$ borave u Beogradu i nastoje ublažiti vladine zakonske

${ }^{74}$ Pribićevićeva crkva u Sisku, u: Narodna politika, 31. 10. 1922., 2.; Hrvatski katolički pokret, u: Sisački glas, 5. 11. 1922., 2.

${ }^{75}$ Pribićevićeva crkva u Sisku, 2.; Hrvatska sv. služba Božja, u: Sisački glas, 19. 11. 1922., 1-2.

${ }^{76}$ Reformni pokret Hrvata-katolika, u: Hrvatski katolički kalendar Grgur Ninski, Zagreb, 1931., 64.

${ }^{77}$ HDA, Osobni fond Emilija Laszowskog, kut. 64.; Novi protestanti i skizmatici-starokatolici, u: $\check{Z}$ ivot 5(1924.)4, 223.

${ }^{78}$ M. BARBARIĆ, U povodu desetogodišnjice smrti prvog biskupa Hrvatske starokatoličke crkve Marka Kalogjera, u: Glasnik Hrvatske starokatoličke crkve 19(1966.)9, 10.

${ }^{79}$ H. MATKOVIĆ, Prilog proučavanju masonske organizacije u Kraljevini Srba, Hrvata i Slovenaca, u: Historijski zbornik, 29-30 (1976. - 1977.), 529.; Ferdo Šišić pristupio je slobodnozidarskoj loži Maksimilijan Vrhovac u Zagrebu 23. studenog 1923. godine (M. GLOJNARIĆ, Masonerija u Hrvatskoj). 
odredbe protiv HKC-a. ${ }^{80}$ Moguće je da su Vidušić i Šišić pripremali teren kod vlade za novi smjer u kojem će istoga toga mjeseca krenuti cijeli reformni pokret i HKC prema starokatolicizmu. Postavivši temelje za zakonsko priznavanje, reformašima je uspjelo na temelju ustavnih prava dobiti 18. prosinca 1923. i zakonsko priznanje svoje nove Hrvatske starokatoličke Crkve. Ministarstvo vjera potvrdilo je navode predstavke od 7. prosinca i priznalo HSC. Beogradske Službene novine objavile su taj ukaz Ministarstva vjere 24. prosinca 1923., a zagrebačke Narodne novine 11. siječnja 1924. godine. ${ }^{81}$

Stav Katoličke Crkve bio je da je priznavanje HSC-a politički čin, ali ne više Demokratske stranke, nego sada srpske Narodne radikalne stranke: $\gg \mathrm{i}$ to je crkva, koju nose na rukama najprije demokrati (u početku), a onda radikali. ${ }^{82}$ Smatrali su kako je Hrvatska starokatolička Crkva priznata protuustavno i kako je to posljedica političkoga čina: »to je razlog, što su u početku starokatolike podupirali demokrati (Pribićević) a poslije i sada radikali. Slično je kao s Orjunom, jer je i nova crkvica neka Orjuna na crkvenom polju. $\ll^{83}$ Krajem godine u Katoličkom listu izišao je još jedan članak u kojem se na isti način insinuira povezanost legalizacije HSC-a s radikalima. Autor prvo napada reformaške svećenike koji su od $\gg$ vjere otpali svećenici... koji su u službu tatskog, protukatoličkog, protukršćanskog, da i bezbožnog liberalizma... pa su te svrzimantije bacile u blato svoj katolički, hrvatski i svećenički značaj. Oni su puko svjesno oružje u rukama naših narodnih neprijatelja $\ll^{84}$. U nastavku teksta autor precizira svoje optužbe o povezanosti HSC-a i radikala kada kaže:

»'Reformaški svećenici’ postali su puko orudje u rukama onih naših narodnih i vjerskih neprijatelja, koji nastoje hrvatski narod prevesti na pravoslavlje, a u nas je pravoslavlje istovjetno sa srpstvom. Da je doista tako, s pravom zaključujemo odatle: 1 . što je vlada svim tim 'reformaškim' svrzimantijama odma podijelila lijepe službe; 2 . što je podupirala usprkos prosvjeda katoličkog hrvatskog episkopata i protuustavno taj 'reformaški' pokret; 3. što im je dozvolila da protuzakonito kao otpadnici javno služe sv. misu; 4. što ih dandanas, ako i potajice, podupire i zaštiću-

\footnotetext{
${ }^{80}$ Usp. Iz $\gg$ Hrvatske narodne crkve «, u: Katolički list (1923.)46, 559.; HDA, Osobni fond Emilija Laszowskog, kut. 64.; Vladine odredbe o t. zv. hrv. reformnoj crkvi, u: Narodne novine, 31. 3. 1923., 1-2; Nadbiskupijski arhiv u Zagrebu (dalje: NAZ), Dnevnici nadbiskupa Bauera, IV, 26. IX. 1922.; Iz Hrvatske narodne crkve, u: Katolički list (1923.) 46, 559.

${ }^{81}$ Reformni pokret Hrvata-katolika, 66.

${ }^{82}$ Novi protestanti i skizmatici-starokatolici, 225.

${ }^{83}$ Isto, 227.

${ }^{84}$ Osvrt, u: Katolički list (1923.)52, 642.
} 
je; 5. što su u Češkoj isto takovi 'reformaši' i istoga programa prešli javno i formalno na pravoslavlje i to uz javnu agitaciju srpskog pravoslavnog episkopa Dositeja. ${ }^{85}$

Oglasila se i sarajevska Nedjelja koja nastanak HSC-a dovodi u vezu s radikalima:

$\gg$ Otkako je naša radikalska beogradska vlada našim žutim svrzimantijama odobrila pangermasnku vjersku sljedbu 'staro-katolika' traže ovi glasnici na sve strane pristaše da im da im omoguće osnutak barem jedne 'staro-katoličke' crkvene općine. Oblijeću naročito oko javnih konkubinaraca i obećaju im da će im pozakoniti konkubinate... I radi ove nekolicine skrhanih tipova išla se državna vlast ponizivati pa izdavati odluku o priznanju jedne sekte, u našem narodu dosada sasvim nepoznate. $\ll^{86}$

Očiti cilj spomenutih političkih stranaka i slobodnih zidara bio je sustavno slabljenje utjecaja i ugleda Katoličke Crkve s obzirom na njezinu važnu ulogu u obrani hrvatskoga nacionalnoga i kulturnoga identiteta u državi koja je sve više poprimala centralistička i totalitaristička obilježja. Također treba istaknuti kako su hrvatske političke stranke, pa dijelom i sama Hrvatska pučka stranka, i dalje lutale u novonastalim političkim okolnostima, dok je Katolička Crkva, u početcima i sama sklona ujedinjenju, prva osjetila udarce novoga režima na svoje institucije zbog snažne i velike uloge koju je imala u hrvatskom društvu.

${ }^{85}$ Isto, 643.

${ }^{86}$ Uspjesi pangermanske »staro-katoličke«s sljedbe, u: Nedjelja, 3. 2. 1924., 6. 


\section{POLITICAL SUBJECTS IN RELATION TO THE REFORM MOVEMENT AND OLD CATHOLICISM \\ - POLITICAL ACTION TO WEAKEN THE CATHOLIC CHURCH IN THE KINGDOM OF SERBS, CROATS AND SLOVENES UNTIL 1929 (I.)}

\section{Daniel PATAFTA*}

Summary: The Croatian Old Catholic Church was founded at the end of 1923 as a failed attempt by the reform movement of part of the lower ranked Catholic clergy, which in the period from 1919 to the end of 1923 sought to reform and democratize the Catholic Church in the Kingdom of Serbs, Croats and Slovenes, but also at the encouragement of Belgrade governments, initially the independent democrats of Svetozar Pribicević, associated with the Freemasons, and later the Greater Serbia Radical Party, which gave it direct and indirect support in institutionalization and expansion, thus showing its antagonism to Catholicism. All political entities until 1929 that supported the reform movement and the Croatian Old Catholic Church did so out of political opportunism in order to weaken the social and political influence of the Catholic Church among the Croatian people, but also out of their own ideological beliefs.

Keywords: reform movement, Croatian Old Catholic Church, political Catholicism, Pribićević, Stjepan Radić, Serbian radicals, Freemasons, Catholic Church, political opportunism.

* Asst. Prof. Daniel Patafta, Ph. D., Catholic Faculty of Theology, University of Zagreb, Vlaška ulica 38, P. O. box 432, 10000 Zagreb, Croatia,d.patafta@yahoo.com 